\title{
The Impact of Oral Health on the Quality of Life in Elderly Patients
}

\author{
Milena Kostić1,2, Marko Igić ${ }^{1,2}$, Ana Pejčićc ${ }^{1,2}$ \\ ${ }^{1}$ University of Niš, Faculty of Medicine, Niš, Serbia \\ ${ }^{2}$ Clinic of Dentistry, Niš, Serbia
}

SUMMARY

Poor oral hygiene and diseases of the teeth and oral tissues can affect all aspects of patients' lives.

The aim of the study was to determine the subjective assessment of oral and general health and their impact on the quality of life in elderly patients.

The research included 46 patients, geriatric center users, who were asked questions from a threepart questionnaire. The first part of the questionnaire referred to the basic sociodemografic data. The second part of the questionnaire was the modified Oral Impacts of Daily Performance (OIDP), followed by an assessment of general and oral health by the patient. Likert's five-step scale (1 - 5) determined the frequency and intensity of the difficulties encountered, as well as the subjective assessment of the state of health.

Based on the modified OIDP questionnaire, we found that all patients had some difficulties due to oral complaints. Even $86.96 \%$ of patients, due to with the existence of oral symptoms, experienced eating disorders, difficulties in enjoying food, laughing and showing teeth without any discomfort, as well as enjoying socializing with other people. Patients with partial edentulism had higher OIDP scores than edentulous patients. OIDP scores did not depend on sex, marital status, or on the educational structure of patients. Respondents with serious difficulties had a statistically significantly higher need for dental interventions.

Improvement of oral health and frequent dental examinations could improve the functions of the orofacial system, the appearance and self-confidence of patients, which would have a positive impact on their social life.

Key words: oral health, quality of life

Corresponding author:

Milena Kostić

e-mail: kosticmilena76@gmail.com 


\section{INTRODUCTION}

Oral health care of elderly patients has become an extremely important parameter in dentistry given that life expectancy is being prolonged, therefore, its new branch - geriatric dentistry, has been developing in recent years (1). A preventative program and timely treatment of teeth and oral cavity tissues prevent tooth loss, which is usually associated with the elderly population, which affects mastication, speech and swallowing, simultaneously influencing the physiognomy of the face and a nice smile (2). Poor oral hygiene and oral cavity diseases may result in changes in the general health status of patients $(3,4)$. On the other hand, general diseases and possible infections may negatively affect patients' oral health and, consequently, the quality of their lives (5). According to the definition of the World Health Organization, the elderly population is comprised of individuals older than 65 years of age (6).

Traditionally, the assessment of patients' oral health is related to normative parameters obtained by a clinical check-up, disregarding social, emotional and functional aspects of oral health (6). However, it is those subjective indicators that show how oral health problems affect orofacial functions, as well as the psychological and social aspect of their lives (7). On the other hand, the way of life and surrounding may have an impact on oral health, as well as on the satisfaction with personal life.

The assessment of the impact of oral health on the quality of life of elderly patients may be done using standardized questionnaires (Oral HealthRelated Quality of Life, Oral Impacts of Daily Performance, Oral Health Impact Profile, etc.), which have been translated and culturally adapted for different speaking areas $(2,8-11)$. The questionnaires may be used as a measure which shows how determinants of oral health affect the general health and quality of life of elderly patients, but also as a measure of the effectiveness of promoting health and dental treatments.

\section{AIMS}

The aim of the study was to determine the subjective grade of oral and general health and their impact on the quality of life in elderly patients.

\section{PATIENTS AND METHODS}

The study included 46 patients, residing in wards of the Geriatric centre in Niš, Serbia. It guaranteed identical life conditions regarding accommodation, food, and social activities. Inclusion criteria encompassed patients above 65 years of age in whom cognitive abilities were confirmed based on medical documentation. Prior to the testing, all subjects were informed on the purpose and protocol of the study and they signed the consent. The protocol of the testing was approved by the Ethics Committee of the Clinic of Dentistry of the Medical Faculty in Niš, Serbia (No. 20/6-2018-2 EO).

The subjects were asked questions that define some basic data: gender, level of education, marital status, as well as the condition in the oral cavity such as complete edentulism, partial edentulism and the presence of some kind of prosthetic work.

The second part of the questionnaire contained a modified OIDP (Oral Impacts of Daily Performance) questionnaire for adults in the Serbian language (12), created by translating and cultural modification of the already modified questionnaire by Tsakos et al. (Table 1) (13) using the forward and back-translation method (14). Following the internationally established method, OIDP was translated using the standardized way which consisted of a translation from English into Serbian, a reverse translation and a pilot study (12).

As a dichotomous variable, the OIDP questionnaire examined the presence of difficulties in performing ten basic daily activities. In the event of the presence of these difficulties, their frequency and intensity were determined on the basis of the positive Likert five-point scale $(1-5)$. The score of the modified OIDP questionnaire in the Serbian language was the sum of the scores of all 10 activities, each of which was obtained as the product of the intensity of the difficulties and their frequency divided by the maximum value of the score, multiplied by 100. A higher score corresponded to a worse status, that is, a greater difficulty. The questions were simple, as were the answers offered, and the examiners, if needed, explained them but without any suggestions.

In the third part of the self-perception questionnaire, patients were asked to define their general health on the Likert scale from 1 to 5 , as well 
Table 1. Modified OIDP questionnaire

1 : Have you had any difficulties during the last 6 months because of problems with your mouth, teeth or dental appliances?

*If the answer is "no" you will mark "0" and assess the presence of difficulties during the next activity/behavior!

* If yes, you need to fill out the remaining questions $(2-4)$

2: How often have you had these difficulties in the last 6 months?

5 - almost every day or every day

4- 3-4 times a week

3- once or twice a week

2- once or twice a month

1 - less than once a month

3: How long have you had these difficulties in the last 6 months?

5 - over 3 months

4- from 2-3 months

3- from 1-2 months

2- from 5 days to 1 month

1 - up to 5 days

4: Using a scale of 0 to 5 , where 0 means a small impact, and 5 signifies a very serious impact, what number in your opinion would best reflect the impact of the difficulty on your everyday life?

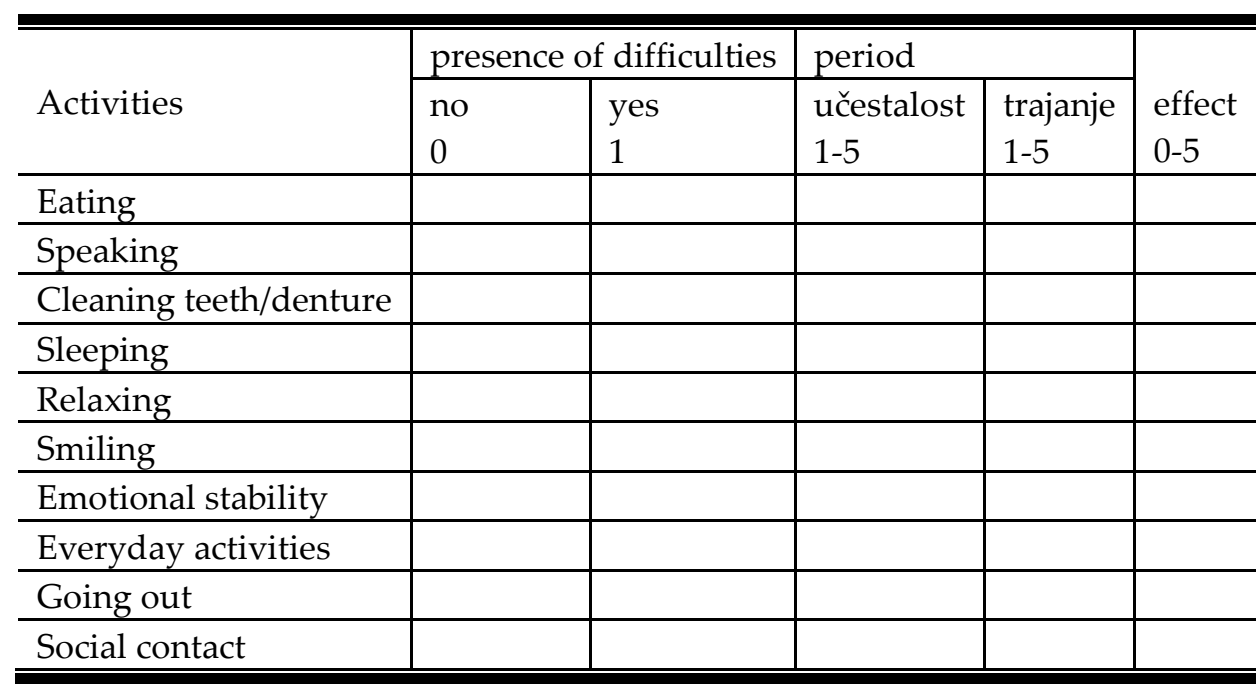

as the health condition of the oral cavity, with higher values corresponding to a better health condition (9). Patients also assessed the need for a dental intervention on the Likert scale from 1 to 5 , whereby higher values corresponded to a greater need for a dental intervention.

\section{Statistical processing of data}

The examined qualitative parameters were shown by frequency and in percentages, the scores by mean values, standard deviations, and medians, whereas the normality of those continuous variables was determined using the Shapiro-Wilk test. As it was shown that the distributions were normal, the comparison of the score values among groups defined by values of dichotomous variables was done using the Student t-test, whereas among groups defined by variables with more modalities the same was done using the ANOVA and a subsequent Post Hoc analysis. The correlation of the score of the modified OIDP questionnaire with the variables from the third part of the questionnaire whose distribution deviates from normal was de- 
fined by the Spearman's rank correlation coefficient $\rho$. The reliability of scales was determined using the Cronbach's alpha coefficient.

\section{RESULTS}

The tests carried out at the Geriatric centre, under almost identical demographic and socioeconomic conditions, represented an explicit testing model that produced relevant and comparable results.

Demographic characteristics and state of the patient's mouth are given in Table 2 .

In Table 3, the patients numerically assessed their general and oral health based on their own perception, as well as the need for dental intervention.

The modified OIDP questionnaire determined that all the patients had some sort of difficulty as a consequence of issues in the oral cavity (Table 4).

The values of Cronbach's alpha subscores (higher than 0.70) and corrected correlation coefficients (higher than the recommended 0.20) indicated an excellent internal consistency of the OIDP
Table 2. Demographic characteristics and state of the patient's mouth

\begin{tabular}{l|l|l}
\hline \hline GENDER & \multicolumn{2}{|c}{} \\
\hline \multirow{2}{*}{$\begin{array}{l}\text { Male } \\
\text { Female }\end{array}$} & 23 & $50.00 \%$ \\
\cline { 2 - 3 } LEVEL OF EDUCATION & 23 & $50.00 \%$ \\
\hline \multirow{2}{*}{$\begin{array}{l}\text { Basic } \\
\text { Hedium }\end{array}$} & 9 & \\
\cline { 2 - 3 } PhD & 24 & $52.17 \%$ \\
\cline { 2 - 3 } MARITAL STATUS & 11 & $23.91 \%$ \\
\cline { 2 - 3 } Married & 2 & $4.35 \%$ \\
\hline \multirow{2}{*}{$\begin{array}{l}\text { Widowed } \\
\text { Divorced }\end{array}$} & 14 & $30.43 \%$ \\
\cline { 2 - 3 } Unmarried & 14 & $30.43 \%$ \\
\cline { 2 - 3 } ORAL CAVITY STATUS & 12 & $26.09 \%$ \\
\cline { 2 - 3 } $\begin{array}{l}\text { Edentulism } \\
\text { Partial edentulism }\end{array}$ Some kind of prosthetic appliances & 6 & $13.04 \%$ \\
\cline { 2 - 3 } & 28 & $60.87 \%$ \\
\cline { 2 - 3 } & 21 & $45.65 \%$ \\
\hline \hline
\end{tabular}

* The data is given as a frequency and percentage

Table 3. Assessment of general and oral cavity health and the need for dental intervention

\begin{tabular}{l|c|c|c}
\hline \hline GENERAL HEALTH CONDITION & $2.83 \pm$ & 1.02 & $(3.00)$ \\
\hline Extremely bad & & 4 & $8.70 \%$ \\
\cline { 2 - 4 } Bad & & 14 & $30.43 \%$ \\
\cline { 2 - 4 } Good & & 16 & $34.78 \%$ \\
\cline { 2 - 4 } Very good & & 10 & $21.74 \%$ \\
\cline { 2 - 4 } Excellent & $2.39 \pm$ & 2 & $4.35 \%$ \\
\hline ORAL HEALTH CONDITION & & 6 & $(2.00)$ \\
\hline Extremely bad & & 22 & $43.04 \%$ \\
\cline { 2 - 4 } Bad & & 12 & $26.09 \%$ \\
\cline { 2 - 4 } Good & & 6 & $13.04 \%$ \\
\cline { 2 - 4 } Very good & & 0 & $0.00 \%$ \\
Excellent & $3.57 \pm$ & 1.26 & $(4.00)$ \\
\hline DO YOU NEED A DENTAL INTERVENTION? & & 4 & $8.70 \%$ \\
\hline No, everything is fine. & & 6 & $13.04 \%$ \\
\cline { 2 - 4 } No, I'm not planning. & & 8 & $17.39 \%$ \\
\cline { 2 - 4 } I should have a check-up. & & 16 & $34.78 \%$ \\
\cline { 2 - 4 } $\begin{array}{l}\text { Probably. } \\
\text { Definitely. }\end{array}$ & & 12 & $26.09 \%$ \\
\hline \hline
\end{tabular}

* The frequencies of given responses were given as frequencies and percentages. Scores are given as mean values \pm standard deviations (median) 
Table 4. The occurrence of difficulties due to oral issues in performing usual everyday activities

\begin{tabular}{l|l|l}
\hline \hline AKTIVITES & \multicolumn{2}{|c}{} \\
\hline Eating & 40 & $86.96 \%$ \\
\hline Speaking & 24 & $52.17 \%$ \\
\hline Cleaning teeth/denture & 21 & $45.65 \%$ \\
\hline Sleeping & 9 & $19.57 \%$ \\
\hline relaxing & 10 & $21.74 \%$ \\
\hline Smiling & 40 & $86.96 \%$ \\
\hline Emotional stability & 36 & $78.26 \%$ \\
\hline Everyday activities & 32 & $69.57 \%$ \\
\hline Going out & 26 & $56.52 \%$ \\
\hline Social contact & 40 & $86.96 \%$ \\
\hline The data is given as a frequency and percentage
\end{tabular}

index, and Cronbach's alpha of the modified OIDP of 0.77 was higher than the recommended (Table 5).

The values of Cronbach's alpha coefficients when eliminating certain subscores suggested that

Table 5. Internal consistency of the Serbian version of the modified OIDP questionnaire

\begin{tabular}{l|c|c}
\hline \hline \multicolumn{1}{c|}{ ACTIVITES } & $\begin{array}{c}\text { Corrected } \\
\text { item-total } \\
\text { correlation }\end{array}$ & $\begin{array}{c}\text { Cronbach's } \\
\text { alpha } \\
\text { If item } \\
\text { deleted }\end{array}$ \\
\hline Eating & 0.28 & 0.78 \\
\hline Speaking & 0.34 & 0.77 \\
\hline Cleaning teeth/denture & 0.26 & 0.77 \\
\hline Sleeping & 0.27 & 0.77 \\
\hline relaxing & 0.47 & 0.76 \\
\hline Smiling & 0.72 & 0.71 \\
\hline Emotional stability & 0.68 & 0.72 \\
\hline Everyday activities & 0.71 & 0.72 \\
\hline Going out & 0.62 & 0.74 \\
\hline Social contact & 0.38 & 0.77 \\
\hline \hline
\end{tabular}

${ }^{*}$ Cronbach's alpha $=0.77$

smiling and showing teeth without discomfort, as well as the emotional state (irritability) and performing simple everyday activities, are the most important factors of the OIDP scale. If when eliminating such a score Cronbach's alpha is lower than Cronbach's alpha for OIDP score, the subscore is con- sidered important, i.e. it increases it.

Patients with partial edentulism had higher values of the OIDP score compared to the ones with complete edentulism. However, the Student t-test of independent samples did not find a statistically significant difference. It is evident that the OIDP score did not differ regardless of the presence of prosthetic works (Table 6).

When determining the impact of the condition assessment by the patients themselves, the grouping of variables was carried out due to a low frequency of their certain modalities, and the OIDP score dependence in relation to the condition assessment was determined by the ANOVA analysis. Evidently, the value of OIDP increased with poor general and oral cavity health condition, and it was also associated with a greater need for dental intervention. The ANOVA analysis confirmed the statistically significant dependence on the assessment of the health status of the oral cavity and a need for medical intervention at a statistical significance level of $\mathrm{p}<0.05$. The Post Hoc analysis determined a statistically considerably higher OIDP score value in patients who planned a dental intervention compared to the ones who did not mention such a possibility $(\mathrm{p}<0.05)$.

The correlation of OIDP score values with the values of Likert scales for the assessment of general and oral cavity health, using the Spearman's correlation coefficient, determined a statistically significant negative correlation of the OIDP score with the 
Table 6. The value of OIDP scores regarding partial edentulism, the presence of prosthetic works, general and oral cavity health, and the assessment of the need for dental intervention

\begin{tabular}{|c|c|c|c|c|}
\hline \multirow{2}{*}{$\begin{array}{l}\text { PARAMETER } \\
\text { Partial edentulism }\end{array}$} & \multicolumn{3}{|c|}{ OIDP score } & \multirow[t]{2}{*}{ p } \\
\hline & & & & \\
\hline Yes & $32.98 \pm$ & 16.18 & $(35.20)$ & $0.2526^{\mathrm{a}}$ \\
\hline No & $27.24 \pm$ & 17.35 & $(26.80)$ & \\
\hline \multicolumn{5}{|l|}{ Presence of prosthetic works } \\
\hline \multirow{2}{*}{$\begin{array}{l}\text { Yes } \\
\text { No }\end{array}$} & $30.43 \pm$ & 16.52 & (27.40) & $0.9715^{\mathrm{a}}$ \\
\hline & $30.24 \pm$ & 17.68 & $(27.00)$ & \\
\hline \multicolumn{5}{|l|}{ General health } \\
\hline \multirow{3}{*}{$\begin{array}{l}\text { Extremely bad and bad } \\
\text { Good } \\
\text { Very good and exellent }\end{array}$} & $32.91 \pm$ & 15.42 & $(27.00)$ & \\
\hline & $29.00 \pm$ & 15.58 & $(29.40)$ & $0.7154^{\mathrm{b}}$ \\
\hline & $28.33 \pm$ & 20.90 & $(26.60)$ & \\
\hline \multicolumn{5}{|l|}{ Oral cavity health } \\
\hline \multirow{3}{*}{$\begin{array}{l}\text { Extremely bad and bad } \\
\text { Good } \\
\text { Very good and exellent }\end{array}$} & $35.57 \pm$ & 17.92 & $(37.80)$ & \\
\hline & $23.70 \pm$ & 10.08 & $(26.00)$ & $0.0239^{b}$ \\
\hline & $19.33 \pm$ & 13.16 & $(15.60)$ & \\
\hline \multicolumn{5}{|l|}{ Need for dental intervention } \\
\hline \multirow{3}{*}{$\begin{array}{l}\text { No or I do not have a plan } \\
\text { Control is needed } \\
\text { Probably or obligatory }\end{array}$} & $18.60 \pm$ & 11.71 & $(16.20)$ & \\
\hline & $27.75 \pm$ & 11.25 & $(27.40)$ & $0.0196^{\mathrm{b}}$ \\
\hline & $35.30 \pm$ & $17.68^{*}$ & $(37.40)$ & \\
\hline
\end{tabular}

* Scores are given as mean values \pm standard deviations (median) $\mathrm{a}$ - Student's t-test of independent samples; b-ANOVA

Table 7. Spearman's correlation coefficient of OIDP scores with scales for the assessment of general and oral cavity health and need for dental intervention

\begin{tabular}{lrc}
\hline \hline The correlation of OIDP score & $\rho$ & $\mathrm{p}$ \\
\hline General health & -0.16 & 0.2899 \\
Oral cavity health & -0.33 & 0.0268 \\
Do you need a dental intervention? & 0.33 & 0.0230 \\
\hline \hline
\end{tabular}

assessment of the oral cavity health, and a positive correlation with the assessment of the need for dental intervention $(\mathrm{p}<0.05)$ (Table 7).

\section{DISCUSSION}

The number of issues associated with the health of teeth and soft tissues of the oral cavity increases with age. The study started from the assumption that poor oral health and tooth loss have a negative impact on the quality of life of the subjects, given that they affect mastication and other func- tions or the orofacial system, the degree of satisfaction of the physical appearance and personal life, as well as the perception whether, and to what extent, they need a check-up or dental intervention.

The study included wards of the Geriatric centre with the population above the age of 65 , who formed a homogenous group of subjects who lived under identical conditions, fed in the same way and received the same health care. Previous studies have shown that geriatric centre service users have an increased risk of developing caries, periodontal disease, and tooth loss $(3,15)$. Rabbo et al. associate 
poor oral health in geriatric centres with poor professional dental care, loss of motivation, difficult motor functions, and inadequately trained staff about the need for oral care (16). The study used a modified OIDP which focuses on the effects which oral health components have on the everyday life of patients. This questionnaire is a multi-dimensional construction that combines the subjective assessment of oral health, degree of physical abilities, emotional well-being, expectations, and personal satisfaction. The questions from the questionnaire referred to the period which covered the previous six months. The questionnaire helped determine the subjects who had some kind of an issue associated with their oral health. $86.96 \%$ of the subjects had issues associated with mastication and the choice of food they could eat, which undoubtedly indicated the lack of or the use of inadequately made dentures. Nutrition problems are associated with gastrointestinal disorders, as well as with malnutrition in elderly patients. Based on the obtained results, it was concluded that the subjects needed dental care, even though some of them thought the opposite. Irritability was present in $78.26 \%$ of the subjects, whereas $69.57 \%$ experienced difficulties performing everyday activities.

OIDP scores suggested that oral problems considerably decreased psychological stability, contacts with other people and feeling of relaxation when socializing. Great discomfort and insecurity when smiling negatively affected the quality of social life, making the subjects feel lonely and withdraw into themselves. The cumulative effect of different parameters resulted in apathy as well as difficulties in performing everyday activities, which demotivated these patients from visiting a dentist and solving their problem.

The studies of Fuentes-Garcia et al. (17) and Erić et al. (10) proved that the level of education affects the results of the questionnaire. On the contrary, the results obtained in this research indicate that the OIDP score does not depend on the sex, marital status, nor on the educational level of patients.

The value of OIDP scores was higher in patients with partial edentulism compared to the ones with complete edentulism, but with no statistical significance. What was interesting is that the OIDP score did not differ regarding the presence of prosthetic works, which may be justified by their deterioration and inadequacy. Gerristen et al. also concluded that the larger number of teeth in the jaws, the better quality of life (18). The correlation of OIDP score values with the values of Likert's scales for the assessment of general and oral health determined that there was a statistically significant negative correlation of the OIDP score with the health assessment of the oral cavity, which indicates that the poor health of the oral cavity (lower score value) is associated with higher OIDP score values, i.e. greater difficulties in performing everyday activities. Moreover, a statistically significant positive correlation of OIDP scores with the assessment of the need for dental intervention $(p<0.05)$ was proven, therefore, the subjects with serious difficulties had a higher need for dental interventions. Rebelo et al. came to a conclusion that the improvement of oral health also improved the quality of life of elderly patients, which is in accordance with the results of this study (2). Furthermore, Leinart et al. demonstrated a great reduction of the effect of oral factors on performing everyday activities prior to and after the treatment of oral cavity diseases (8). Gerson et al. (19), as well as Dunnell and Cartwright (20), did not consider oral health important for the overall health of patients, regarding it as an unpleasant experience and a personal problem of an individual. Nowadays, oral health has been proven to be a factor which plays a very important role in preserving general health. On the other hand, the study of Petrović et al. suggested a very low level of oral health of elderly people in geriatric centres in Serbia, which consequently has a negative impact on their everyday activities and the quality of life (9). Erić et al. indicated poor oral hygiene in elderly patients (10). The help of medical staff in motivating patients and proper maintenance of oral hygiene could improve their general health and quality of life (21 - 25). Stančić et al. suggested special trainings on oral care, even though they pointed to the lack of protocols and standards which trainers would use to train staff in geriatric centres (15). The same trainings could be used in health institutions, all in order to improve the health and quality of life of elderly patients (26).

\section{CONCLUSION}

The analysis of the data obtained in the study found that all subjects had certain oral health problems which had been affecting their everyday activities and the quality of life for the previous six 
months. The OIDP score did not depend on the sex, marital status, nor the educational level of the subjects. The subjects with serious difficulties had a statistically significantly higher need for dental interventions. Improving oral health and regular dental check-ups would improve the functions of the orofacial system, physical appearance, and self-confidence of the subjects, as well as their social life.

\section{Acknowledgements}

This work was supported by the Internal project of the Faculty of Medicine, University of Niš, Serbia. No. 1114629-4/11.

\section{References}

1. Mariko N, Tomohisa K, Wataru F, et al. Effects of dental treatment on the quality of life and activities of daily living ininstitutionalized elderly in Japan. Arch Gerontol Geriatr 2010; 50(1): 65-8.

2. Rebelo MAB, Cardoso EM, Robinson PG, Vettore MV. Demographics, social position, dental status and oral healthrelated quality of life in community-dwelling older adults. Qual Life Res 2016; 25:1735-42. https://doi.org/10.1007/s11136-015-1209-y

3. Hebling E, Pereira AC. Oral health-related quality of life: a critical appraisal of assessment tools used in elderly people. Gerodontology 2007; 24(3): 151-61.

https://doi.org/10.1111/j.1741-2358.2007.00178.x

4. Tsakos, G. Inequalities in oral health of the older: Rising to the public health challenge? J Dent Res 2011; 90:689-90. https://doi.org/10.1177/0022034511407072

5. Locker, D, Allen, F. What do measures of 'oral healthrelated quality of life' measure. Community Dentistry and Oral Epidemiology 2007; 35: 401-11. https://doi.org/10.1111/j.1600-0528.2007.00418.x
6. Vogt D, Schaeffer D, Messer M, et al. Health literacy in old age: results of a German cross-sectional study. Health Promot Int 2018; 33(5):739-47. https://doi.org/10.1093/heapro/dax012

7. Seenivasan MK, Banu F, Inbarajan A, et al. The Effect of Complete Dentures on the Quality of Life of Edentulous Patients in the South Indian Population Based on Gender and Systemic Disease. Cureus 2019;11(6):e4916. https://doi.org/10.7759/cureus.4916

8. Lajnert V, Gržić R, Radica N, et al. Translation and validation of the Croatian version of the Oral Impacts on Daily Performances (OIDP) scale Vojnosanit Pregl 2016; 73(9): 811-6. https://doi.org/10.2298/VSP140829136L

9. Petrović M, Stančić I, Popovac A, Vasović M. Oral health-related quality of life of institutionalized elderly in Serbia. Vojnosanit Pregl 2017; 74(5): 4029. https://doi.org/10.2298/VSP150720228P

10. Eric J, Stancic I, Tihacek-Sojic LJ, et al. Prevalence, severity, and clinical determinants of oral impacts in older people in Bosnia and Herzegovina. Eur J Oral Sci 2012; 120: 438-43. 
https://doi.org/10.1111/j.1600-0722.2012.00994.x

11. Kuo HC, Chen JH, Wu JH, et al. Application of the Oral Health Impact Profile (OHIP) among Taiwanese elderly. Qual Life Res 2011; 20:1707-1713 https://doi.org/10.1007/s11136-011-9901-z

12. Stančić I, Kulić J, Tihaček-Šojić Lj, Stojanović Z. Applicability of a Serbian version of the "Oral Impacts on Daily Performance (OIDP)" index assessment of oral health-related quality of life. Vojnosanit Pregl 2012; 69(2): 175-80. https://doi.org/10.2298/VSP1202175S

13. Tsakos G, Marcenes W, Sheiham A. Evaluation of a modified version of the index of Oral Impacts On Daily Performances (OIDP) in elderly populations in two European countries. Gerodontology 2001; 18:121-30.

https://doi.org/10.1111/j.1741-2358.2001.00121.x

14. Kristjansson EA, Desrochers A, Zumbo B. Translating and adapting measurement instruments for cross-linguistic and crosscultural research: A guide for practitioners. Can J Nurs Res 2003; 35(2): 127-42.

15. Stančić I, Petrović M, Popovac A, et al. Caregivers' attitudes, knowledge and practices of oral care at nursing homes in Serbia. Vojnosanit Pregl 2016; 73(7): 668-73.

https://doi.org/10.2298/VSP141001065S

16. Rabbo MA, Mitov G, Gebbart F, Pospiech. Dental care and treatment needs of elderly in nursing homes in Saarland: perceptions of homes managers. Gerodontology 2011; 29(2): 57-62. https://doi.org/10.1111/j.1741-2358.2010.00409.x

17. Fuentes-Garcia, A, Lera L., Sanchez, H, Albala C. Oral health-related quality of life of older people from three South American cities. Gerodontology 2013; 30: 67-75. https://doi.org/10.1111/j.1741-2358.2012.00649.x

18. Gerritsen AE, Allen PF, Witter DJet al. Tooth loss and oral health-related quality of life: A systematic review and meta-analysis. Health Qual Life Outcomes 2010; 8: 126.

https://doi.org/10.1186/1477-7525-8-126

19. Gerson LW. Expectations of "sick role" exemptions for dental problems. J Can Dent Assoc (Tor) 1972; 38(10): 370-2.

20. Dunnell K, Cartwright A. Medicine takers, prescribers and hoarders. London: Routledge and Kegan Paul; 1972.

21. Herriman G, Kerschbaum W. Oral hygiene care and education needs in long-term care facilities in Michigan. Dent Hyg 1990; 174: 196-8.

22. Paulsson G, Fridlund B, Holmén A, Nederfors T. Evaluation of an oral health education program for nursing personnel in special housing facilities for the elderly. Spec Care Dent 1998; 18(6): 234-42. https://doi.org/10.1111/j.1754-4505.1998.tb01640.x

23. Sonde L, Emami A, Kiljunen H, Nordenram G. Care providers' perceptions of the importance of oral care and its performance within everyday caregiving for nursing home residents with dementia. Scand J Caring Sci 2011; 25(1): 92-9. https://doi.org/10.1111/j.1471-6712.2010.00795.x

24. Gonzalez EE, Nathe CN, Logothetis DD, et al.. Training caregivers: disabilities and dental hygiene. Int J Dent Hyg 2013; 11(4): 293-7.

https://doi.org/10.1111/idh.12019

25. Paulsson G, Söderfeldt B, Nederfors T, Fridlund B. Nursing personnel's views on oral health from a health promotion perspective: a grounded theory analysis. Acta Odontol Scand 2002; 60(1): 42-9.

https://doi.org/10.1080/000163502753471998

26. Fiske J, Griffiths J, Jamieson R, Manger D. Guidelines for oral health care for long-stay patients and residents. Gerodontology 2000; 17(1): 55-64. https://doi.org/10.1111/j.1741-2358.2000.00055.x 


\title{
Uticaj oralnog zdravlja na kvalitet života kod bolesnika starije životne dobi
}

\author{
Milena Kostić1,2, Marko Igić1,2, Ana Pejčić1,2 \\ ${ }^{1}$ Univerzitet u Nišu, Medicinski fakultet, Niš, Srbija \\ ${ }^{2}$ Klinika za stomatologiju, Niš, Srbija
}

\section{SAŽETAK}

Loša higijena i bolesti zuba i oralnih tkiva mogu uticati na sve aspekte života bolesnika.

Cilj istraživanja bilo je utvrđivanje subjektivne ocene oralnog i opšteg zdravlja bolesnika i njihovog uticaja na kvalitet života bolesnika starije životne dobi.

Istraživanje je obuhvatilo 46 bolesnika, korisnika gerijatrijskog centra, kojima su postavljana pitanja iz trodelnog upitnika. Prvi deo upitnika odnosio se na osnovne socio-demagrafske podatke. Drugi deo upitnika bio je modifikovani Oral Impacts of Daily Performance (OIDP), nakon čega je sledila procena opšteg i oralnog zdravlja od strane bolesnika. Likertovom petostepenom skalom (1 - 5) utvrđivana je frekvencija, utvrđivan je intenzitet nastalih poteškoća i utvrđivana je subjektivna procena zdravstvenog stanja.

Na osnovu modifikovanog OIDP upitnika utvrđeno je da svi bolesnici imaju neku poteškoću, koja je posledica oralnih tegoba. Čak $86,96 \%$ bolesnika imalo je poteškoće u jelu i uživanju u hrani, smejanju i pokazivanju zuba bez nelagodnosti, kao i u uživanju u druženju sa drugim ljudima, zbog oralnih tegoba. Bolesnici sa krezubošću pokazivali su veće vrednost OIDP skorova u odnosu na bezube, ali na osnovu Studentovog t-testa nezavisnih uzoraka, nije utvrđena statistički značajna razlika. OIDP skorovi nisu zavisili od pola, bračnog statusa, kao ni od obrazovne strukture bolesnika. Ispitanici sa ozbiljnijim poteškoćama imali su i statistički signifikantno veću potrebu za stomatološkim intervencijama.

Poboljšanjem oralnog zdravlja i čestim stomatološkim pregledima mogle bi se unaprediti funkcije orofacijalnog sistema, izgled i samopouzdanje bolesnika, što bi pozitivno uticalo i na njihov socijalni život.

Ključne reči: oralno zdravlje, kvalitet života 